\title{
CHALLENGES AND OPPORTUNITIES IN RESTORATION WORK MANAGEMENT IN CULTURAL HERITAGE. THE CASE OF THE CHURCHES OF SAN MANUEL COLOHETE AND SAN SEBASTIÁN (HONDURAS)
}

\author{
A. Ferrando Ortiz ${ }^{1, *}$ \\ ${ }^{1}$ Universitat Politècnica de València, Spain - adferor@ arq.upv.es
}

Commission II - WG II/8

KEY WORDS: Open for Restoration, Cultural heritage, International cooperation, Restoration work management, Colonial religious heritage, Training workshop

\begin{abstract}
:
The restoration work management in cultural heritage presents lots of difficulties according to the context where it takes place. Some of them are the precarious communication network and civil infrastructures, the absence of specialised local labour or sensitized with cultural heritage whom work with or the need to import suitable materials to develop the project correctly. In the case that arises, the churches of San Manuel de Colohete and San Sebastian (Honduras) converge, among others, all of these difficulties involve the heritage management directly. Besides, the planned work budget is usually reduced and needs the implication of all the actors involved in the project. Therefore, the objective of this work is to identify the difficulties around the development of these restoration works and possible solutions that allow them to achieve the purpose planned. The methodology applied for this article is based on the practical experience and the comparative analysis of cases in similar situations. All of it, in a broad context of citizen participation, in international cooperation actions which takes place in remote and inhospitable geographical areas, where any action is complex. The results refer to the way to solve problems that arise and to the solutions, sometimes creative, which finally make possible the cultural heritage restoration.
\end{abstract}

\section{INTRODUCTION}

In recent decades, the cultural heritage management scene has opened up new areas of work that involve beneficiaries and occasional visitors in restoration projects. Nowadays, there are several examples of good practices that promote heritage education and citizen participation during restoration works.

Spain is an example of this situation, where experiences such as Open for Works in Vitoria or educational initiatives with young people in Ávila within the UNESCO network of historic centres have provided new multidisciplinary working methodologies to architecture professionals.

However, in the Central American context of restoration and social work where projects are inserted, the methodologies are currently being remained in a unidirectional and technical way in which citizen involvement is relegated to reduced spaces.

This work presents one practical experience in the context of small-scale communities that address different aspects of heritage intervention. From a human perspective, the management of the work is linked to the opening up to social processes. This opportunity involves the team working with the communities at the same time as the restoration work is being carried out. The main objective is to promote a connection between all the agents included in the project and allow them to be involved in a physical intervention of restoration with scarce resources.

Through the combination of good practices, the social action program implemented allows the study of the level of identification of the different social groups with their cultural heritage in small towns.

\section{OBJECTIVES AND METHODOLOGY}

\subsection{Objectives}

The case studies carried out are located in small populations where projects are conditioned by the environment and available resources. This circumstance is shared by large restoration works, where the limitations may define how the technical team acts. For this reason, and within the search for a methodological proposal that assists the maximum use of the available resources, the objectives that focus the study are the following:

1. To study and apply methodologies that assist the transformation of a heritage restoration project into a focal point for consciousness-raising inside the community and academic sector.

2. Through heritage education, to develop basic program skills that support the communities to deal with sustainability challenges in resource-poor rural areas in the future.

\subsection{Methodology}

The methodology applied is structured from the observation of the environment and the study of cases. Participant observation is applied to identify the factors that delimit the type of possible actions in the work area. On the other hand, there is an analysis of the project conditions and a case study whose methodologies can be adapted to the identified needs.

Once the methodological itinerary has been designed, the pilot period of implementation and reading of preliminary results takes place.

\footnotetext{
* Corresponding author
} 


\section{STATE OF THE ART}

To locate the project into context, a reading of relevant countrylevel data is presented in parallel to the study of local communities. This information helps to deepen the national structural factors that affect the daily life of the communities where the project takes place.

\subsection{Study of the communities hosting the heritage restoration work}

Honduras has a population of $9,023,838$ people. According to the 2018 UNDP report, Honduras has a Human Development Index of 0.623 and a Multidimensional Poverty Index that represents $19.3 \%$ of the population. It ranks 132nd out of 189 countries $^{1}$ (Conceição, 2019).

In terms of the economy, there are two relevant factors in the country: remittances and official development aid. In the first place, remittances from the Honduran population living abroad represented 20\% of the GDP in 2018 (INE, 2018).

Secondly, the Official Development Assistance received in Honduras has historically been a fundamental support for the country. The analysis carried out in the Country Partnership Framework of the Spanish Agency for International Development Cooperation (AECID) $)^{2}$ points out that "its volume has decreased in recent years, from USD 631 million in 2010 to USD 572 million in 2012, from $4.3 \%$ of GNP to $3.4 \%$ in 2012" (AECID, 2014).

At the regional level, the departments of La Paz, Intibucá, Santa Bárbara, Lempira, Copán and Ocotepeque make up western Honduras. Poverty in this area is among the highest in the country ${ }^{3}$. Most villages are located in rural areas and have an economy based on agriculture and livestock. Coffee is the main export item, which is an internationally demanded product due to its cultivation at high altitudes and varieties with high-quality standards. On the other hand, most of the land is used to cultivate beans and corn like basic products for the population.

San Manuel de Colohete and San Sebastian are two villages that belong to the centre of the department of Lempira. San Manuel is located $32 \mathrm{~km}$ away and San Sebastian $45 \mathrm{~km}$ away from the departmental capital, the city of Gracias. These three towns and La Campa, Belén, and San Marcos Caiquín make up the Colosuca Municipal Association. This institution develops projects focus on the six general strategic lines under which these municipalities are united to face supra-municipal problems, including the management of tourism and its cultural heritage.

With this point of view, the AECID has collaborated since 2002 as a partner institution of the municipal association in heritage conservation projects and other lines like access to water supply and sanitation systems. This is the point of departure for the cases that are presented in this article.

\footnotetext{
1 UNDP Human Development Report. The study considers the country database between 2011 and 2012.

2 Country Partnership Framework (MAP) of the Spanish Agency for International Development Cooperation, the period of 2014-2018. Data is referred to million US dollars (MUSD).

3 The income poverty and multidimensional poverty map drawn up by the National Social Sector Information Centre (CNISS) identifies the departments in the west of the country as the most impoverished area. However, poverty rates are high throughout the country.
}

The protected heritage buildings are mostly the churches of colonial foundation (mainly 18th century), a characteristic in common between these villages. Historically, these churches have been victims of the permanent plundering of their religious images and valuable objects. For this reason, the parish communities keep their churches closed to the public. Related to this situation, it's impossible to any visitor who wants to know the history of the village to access inside these monuments.

\subsection{Needs associated with the project area}

In parallel to the macro database items of the country and the environment searching in which the project is inserted, the participant observation is the methodology applied trough meetings and short visits in the preliminary restoration stage. With these sharing spaces, it is possible to dimension the difficulties and communication protocol with the local community and the representatives of the owner of the monument in the area.

The working line of heritage for development is the main point of view to follow. In these cases, the indicators of cooperation for development projects help to understand the context of a project. The objective is to focus on the implementation of methodologies that contribute to the physical restoration of a heritage building and the social development of the inhabitants living in the beneficiary towns. In other words, this proposal implements heritage training and awareness initiatives at the same time as the work is being carried out.

A third factor to take into account is the follow-up of the development plans of the local institutions, tools that help to assess existing needs in the area of work. In the case of the Colosuca municipal association, the Sustainable Tourism Development Plan for the Destination Colosuca points out the need to "Stimulate the active participation of (local) communities" and proposes "to implement participation mechanisms to facilitate how the local community wants to be involved"4 (Viñals, 2016, p. 22).

\subsection{Challenges and opportunities}

There are two main challenges identified in this case:

1. To design an awareness program adapted to the cultural environment from the same working team that carries out the restoration work of the church.

2. Generate a trusting relationship and identification between the owner, the community and the working project team. In these contexts of difficult access and scarcity of materials, among other limitations, it's necessary to involve the communities in order to achieve the restoration of the building.

In addition to the challenges, the opportunities that exist are assessed. The most outstanding is the possibility of working with multidisciplinary teams covering technical and training areas within the field of international cooperation, with a clear community development objective as a result of the work on heritage.

\footnotetext{
4 The PEDTS is a 2016 document validated by the municipalities of the Colosuca association. There are several strategic guidelines, actions and measures proposed to favour the sustainable tourism development of the region.
} 


\section{PRELIMINARY CASE AND CONTEXT STUDY}

Before starting to design the proposal that will achieve the objectives set out in the project, it is necessary to carry out a preliminary study in two ways: the study of cases with a social perspective applicable in the work area and detailed reading of the factors that define the scope of the proposal.

\subsection{Case studies}

In the first place, a tour of the restoration projects in Honduras is done. Among them is the Comayagua Colonial Program, a project to revitalize the historic centre of Comayagua as an engine of local development in the city. This project was promoted in 1996. In this case, the municipality of Comayagua, the Honduran Institute of Anthropology and History and the AECI created an alliance to develop improvement actions in the centre with four strategic guidelines: to create the Technical Office of the Historical Centre (institutional strengthening), to introduce the Master Plan of the City Centre (urban planning), to develop interventions in the city's monumental buildings (urban regeneration) and to create the Workshop School (labour insertion of young people in restoration-related trades).

The same structure to the one applied in Comayagua was implemented in the Colosuca territory with the Master Plan of the Colosuca Historical City Centres, supported by AECI's Heritage for Development Program in 2002.

In this case, the control and promotion of heritage protection are centralized in a territory of six municipalities from a central office sited in the city of Gracias. Likewise, the Colosuca Workshop School was created in 2006 and continues to operate today, to train young people in trades in demand in the territory.

In order to find examples of wealth management beyond the scope achieved in the country, the search is opened to experiences developed in Spain in the last two decades.

The example that has created a new management model for a restoration project with a related social action is the Cathedral Foundation of Santa María de Vitoria and the Open for Works concept. Under a public-private foundation structure, it has been possible to undertake the restoration of a major heritage building. As indicated by its technical director, the approach of openness to society helps to bring the restoration work closer to the citizens while studying the level of sensitivity between the community and local heritage:

The public presentation of the Master Plan in 1999 provided an opportunity for communication between the promoters and authors of the plan and the citizens of Vitoria, which showed the interest in the conservation of the existing heritage in society, and particularly in the cathedral.(Chamber, 2019).

Nowadays, this initiative which was created as a pioneering concept in 2000 continues its evolution to adapt to the current needs of the building: the maintenance and sustainability of the cultural activities promoted by the foundation.
The Open for Works initiative is currently described as a model of cultural management that allows, as M. Martos describes, that "visitors can not only contemplate the activities and works in progress, but also participate in a different emotional and intellectual experience, in which it is perceived that a historical building, in addition to its other values, is also a document that can be read and understood as an open book." (Martos, 2016, p.82)

This example has been replicated on several occasions throughout Spain. The Spanish Cultural Heritage Institute adapted to its restoration projects in 2018 the visiting model applied in Vitoria under the name Open for Restoration (IPCE, 2018). Similarly, the Community of Madrid has done the same with three cycles of Open for Restoration visits in the territory of the community, the last one in 2016 (PAO, 2016).

On the other hand, the city of Ávila created in 2007 with the support of UNESCO the Patrimonitos programme, within its activities as a World Heritage City Centre (PPA, 2010). This training project for young people addresses to raise awareness of the city's heritage context through training modules for small groups of secondary school students. Through exchanges with other cities, the objective of empowering this sector of the population was achieved, and in the end, they became protectors and protagonists of the local heritage preventive conservation and guides of its relevance to visitors.

\subsection{Delimitation factors}

Through the participant observation methodology, a preliminary study of the delimitation factors at the time of the project execution is carried out. Over a period of one year, all the factors that define the village situation are analyzed to design a program under the possibilities offered by the area of work.

4.2.1 Geographical factors: The department of Lempira is characterised by mountainous geography and difficult access. The road linking the town of Gracias with San Manuel de Colohete and San Sebastian is a dirt road and its conservation status depends on the action of the rains between June and November. Likewise, the communications infrastructure does not reach the entire territory and makes contact between municipalities and coordination of personnel working in the field difficult.

At the same time, there is low availability of public transport between villages; the bus service is limited to journeys in the direction of the capital during the early morning hours and then returns to the villages in the afternoon. All these conditions mobility to the use of four-wheel drive cars prepared for mountainous terrain.

4.2.2 Climatic factors: In Central American countries there are only two seasons a year: the dry season and the rainy season. The rainy season runs from June to November when the rain is heavy and concentrated and streets and ravines are flooded. Associated with this situation, the condition of the roads gets worse quickly during this time and the travelling time is multiplied on the dirt roads that connect inland villages (Figure 1). 


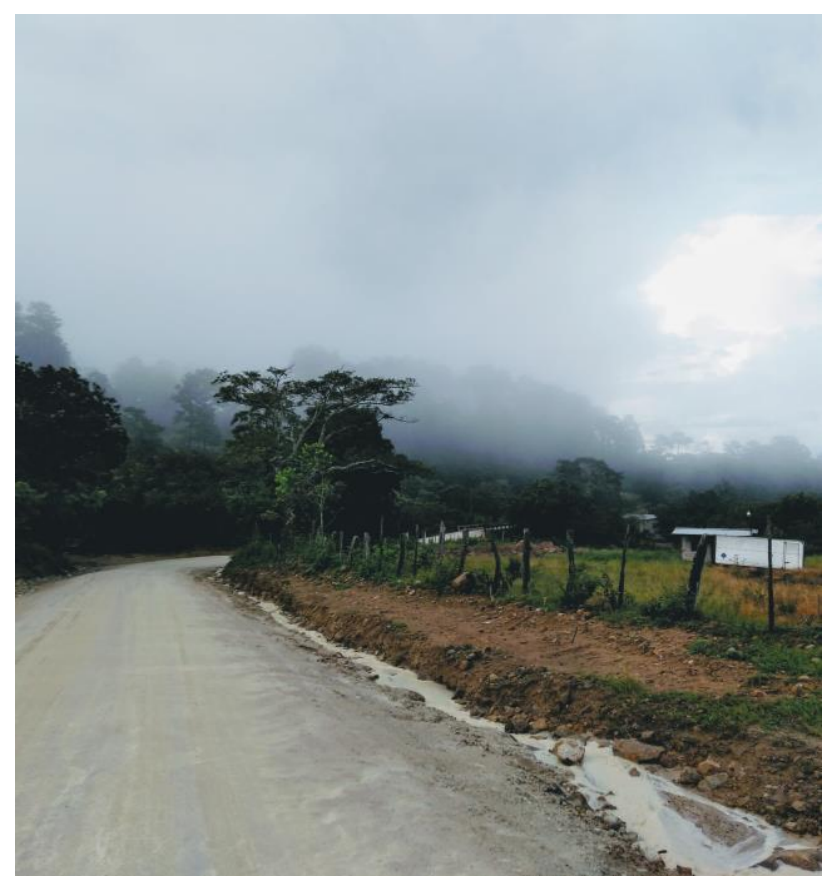

Figure 1. Dirt road between Gracias, San Manuel de Colohete and San Sebastian after a storm (October, 2019). Photograph: Prepared by the author.

4.2.3 Cultural factors: The cultural context is a determining factor on which a project depends. In this case, the rural area is closely linked to subsistence agriculture. The available labour force depends on the planting and harvesting seasons.

The coffee-producing villages in Lempira employ most of the inhabitants of the surrounding villages between December and March. This is the case of San Sebastian. The situation also influences the hiring of local labour, which decreases and becomes more expensive for the other economic activities that are developed in the same months of the coffee harvest.

Another factor that defines the villages is the plundering that has historically destroyed the images and valuable objects of the ancient Catholic temples. For this reason and because of the unavailable own resources designated to have permanent surveillance in the heritage buildings, the temples and communities have been closed to the arrival of visitors who want to know their history.

Associated with this problem, the available information on these temples is scarce and, in some cases, non-existent. Therefore, research and dissemination of historical data on the municipalities and their churches become an added challenge.

On the other hand, the cultural origin of the inhabitants of these villages influences nowadays their structure as a society. San Manuel de Colohete and San Sebastian are two villages $13 \mathrm{~km}$ apart on by a dirt road that starts in the city of Gracias. Despite the short distance between these two urban centres, the cultural difference between them can be seen in the feeling of belonging to the parish community and the way they communicate with people who come from outside.

This difference places the project at different levels to communicate with the inhabitant but with parallel goals within the same methodology of work.
4.2.4 Economic factors: The reduction in Official Development Assistance in recent years has led to a change in small projects. In development heritage projects, this situation is transferred to projects through reduced financing to be implemented in the short term.

However, the new perspective helps to prioritize activities, involve related actors to achieve the goals, respect the possible scope of the project, and favour the continuity of the project in the medium term.

This is a different vision of international cooperation work. Planning a project in phases helps to set gradual short and medium-term objectives that exceed the time set for the execution of physical activities.

4.2.5 Limitations on training courses: The Colosuca Workshop School was founded in 2006 by the objective of training young people in the trades related to carpentry and masonry to support the restorations being carried out in the villages of the association. However, in recent years the needs in the area of construction have been changing and the courses have focused on training for new construction tasks. Therefore, nowadays the search for local specialized professionals in restoration is complicated.

At the country scene there are few people with specialized training practicing the trade. Among them there are still the figures of master builder and master carpentry and masonry graduated in the first classes of the workshop schools of Comayagua and Colosuca.

\subsection{Agents involved in the process}

The restoration of the Catholic churches of San Manuel de Colohete and San Sebastian is planned through a public-private partnership between local government, property owners, national institutions, and the Spanish Agency for International Development Cooperation (Figure 2).
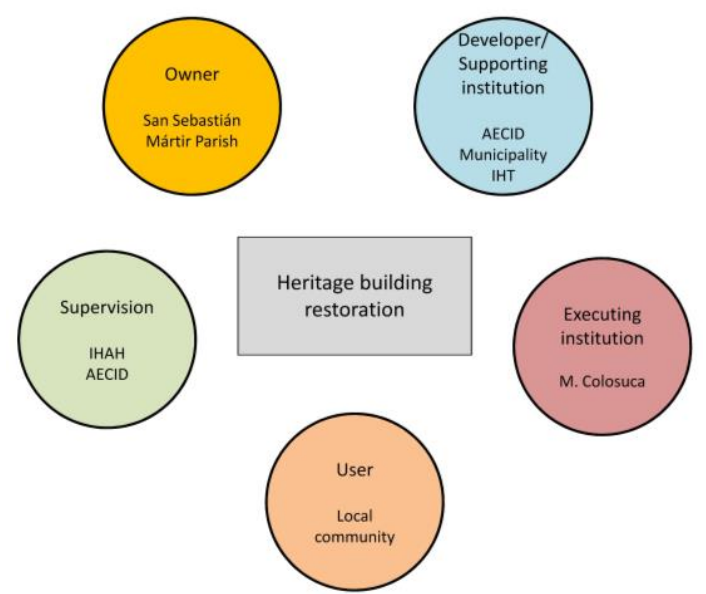

Figure 2. Diagram of agents involved and functions associated with the project. Source: Prepared by the author.

In this case, the role of all agents is coordinated by the Colosuca association, the institution responsible to execute the project. The work approach based on transparency, communication about difficulties and progress, constant supervision, decision making, and joint management of permits is the key to generate a bond of trust between institutions and the local community. 
On the other hand, the existence of a multidisciplinary technical team formed by professionals from the executing institution and the supervisors makes it possible to work on the physical work activities and social processes within the same methodology. In this way, the field team aims to create a clear bridge of communication between the community and the technical office.

However, there is not a full-time human team for the project. That situation makes it necessary to define the scope of the awareness and training programs possible to design with technical and professional resources available. Therefore, the scenario makes it possible to create a pilot programme with a reduced scope to develop the project's social objectives in the short term.

\section{DESIGN AND IMPLEMENTATION OF THE OPEN FOR RESTORATION PROGRAM}

Once the analysis of the context and the corresponding case study has been carried out, the methodological structure of the educational and social programme to be developed in the work area is designed under the name of Open for Restoration.

\subsection{Program structure}

The restoration project in the churches of San Manuel de Colohete and San Sebastian is developed along with three guidelines: the restoration work, a specialized training program in restoration concepts, and the Open for Restoration program as a methodology to use for sensitization and awareness of heritage conservation (Figure 3).

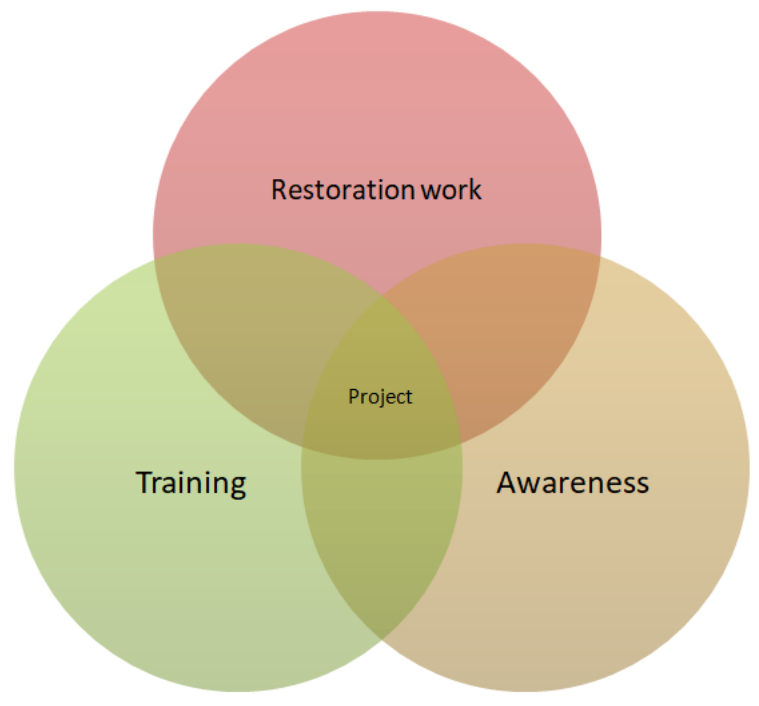

Figure 3. Diagram of strategic guidelines of the project. Source: Prepared by the author.

The three designed strategic guidelines are related to each other to cover the needs in the rural context covered by the project. In other words, each field develops activities that promote support to others as a whole.

For example, the restoration work serves as a platform for guided tours and organized visits promote voluntary support from the local community at specific times during the work. Besides, testimonies are collected from visitors with whom it is possible to record interventions in the temples in recent decades that have not been identified to date.
In terms of awareness, the concept Open for Restoration is being applied for the first time in the country. Because of this reality, it is the highest priority to introduce local authorities and national institutions related to tourism and heritage preservation to this methodology through visits and meetings in which the local technique team explains the objectives being pursued.

The general structure of the programme is organised around three activities:

\begin{tabular}{c|c} 
Action lines of & $\begin{array}{c}\text { Guided tours by the owner and the } \\
\text { technical team in charge of the project }\end{array}$ \\
OR Programme & $\begin{array}{l}\text { Awareness workshops with young } \\
\text { people }\end{array}$ \\
- Documentary research of the heritage \\
element through oral memory
\end{tabular}

This structure mixes the working methodology of the cases studied above. For the project Open for Works, the guided visit by the technical team in charge of the supervision of the work is applied.

In most cases, a representative send by the owner or community is also present during the visit. This person is in charge of explaining the historical and symbolic aspects of the churches. This exercise favours the empowerment of the parish community with its heritage and the creation of direct communication between the inhabitants and the visitors.

On the other hand, the Patrimonitos project has transferred in heritage awareness workshops with organized youth groups that already exist within the community. The objective of this experience is to work on the connection that young people have with the history of their village and to develop small investigations of oral memory on relevant places in their living areas. The final intention is to give back some memorial pieces of their collective memory to the community built from within.

Finally, it is developed a research of the existing historic documents in parallel with the development of the visits. It is planned to make a record of the shared data such as testimonies, photographs, etc., in order to increase the scarce documentation existing in the records on the history of the temples and their communities.

5.1.1 Programme objectives: Taking into account the factors that limit the scope, the proposal has two main objectives: to empower local communities in the protection of their heritage and to open up buildings under restoration to the national academic public as a tool for practical learning within their area of study.

5.1.2 Target audience: There are two main groups targeted by this initiative: local communities and academia.

The first group includes municipal technicians, civil society groups linked to San Sebastian Mártir parish (who has custody of both churches), and, in addition, independent people who want to know the heritage of their town.

The second group is divided by age and academic level. The visit is adapted to schools, institutes, and universities, as well as to the subject with which the activity is associated. In this way, the same heritage element can be showed from many perspectives. 


\subsection{Guided tours}

Dissemination of the program: For the first time in Honduras a guided tour program is implemented during a restoration worksite of these characteristics. In order to disseminate it, regional and national media are called upon to tell the initiative known to as many people as possible. The call is divided into groups at different times of the work and the visit is made with all the technical team (Figure 4).

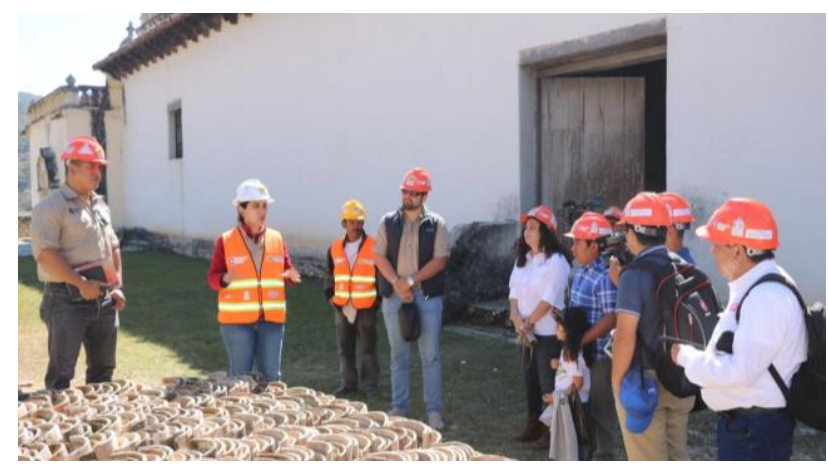

Figure 4. Guided OR program tour to regional media at the first period of restoration works in San Manuel de Colohete. Source: http://www.aecid.hn/sitio/index.php/noticias/531-inician-los-

trabajos-de-restauracion-de-la-iglesia-de-la-inmaculadaconcepcion-de-san-manuel-de-colohete.

At the same time, the technical office personally contacts different universities to arrange specific visits for tourism and architecture degrees. These visits serve as a vehicle for the opening of voluntary professional practices that cover specialized work areas outside the scope of the proposed physical work.

At the local level, visiting groups are organized with the owner. Through the activities within the community, the days and times of the visits are agreed upon and adapted to the possibilities of each place in order to achieve the greatest possible attendance to de guide tours.

Structure of the visit: The visit is organized chronologically. In the first place, the historical data that we have up to now about the building are introduced. In the second place, the structure of the church in the exterior and interior is explained. During this part, images and symbols that differentiate the heritage element from those that exist in the surrounding villages are also analysed. Finally, the restoration work and the new information that is found throughout the execution are explained.

Each visit is different, adapted to the group attending, its age, and level of academic training. The visit speech maintains the structure of three parts that alternate depending on the time of work in which it is carried out. For example, the structural typology is explained from the inside when the roof is fully repaired and finally covered.

In the same way, in the case of San Manuel de Colohete, the visitors who attended the first phase of the work were able to observe the support work done by volunteers from the local community. At that time, there was a group of young volunteers who carry out preventive protection of the polychrome wood in the church (Figure 5). The group was trained as part of the project's training guideline and the technical work team guided the group during the practices. As mentioned above, this is another example of the close relationship between the strategic guidelines of the project.

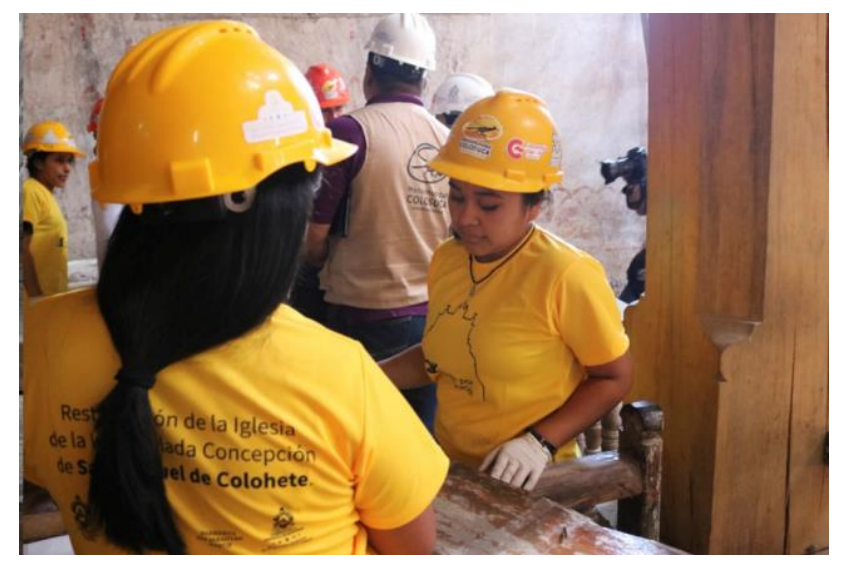

Figure 5. Community volunteers of San Manuel de Colohete working in preventive protection of the polychrome wood in the inside of the church during a guided tour.

Source: http://www.aecid.hn/sitio/attachments/article/540/ Febrero2019.pdf.

On the other hand, a series of visits to the parish community of the village (town centre and small villages) is agreed with the owner. During the visit, the doubts and concerns of the population towards their heritage are clarified. With this cycle of visits, the bond of the community towards the project is strengthened to a great extent based on the transparency and trust between them and the technical executing team.

Record of the visit: With the registration of listings we start to evaluate the attendance, profile, and age of the visitors. Also, a systematization of visits is carried out with a report that collects the most relevant data shared during the day and the doubts and suggestions contributed by the groups. With all this, the speech and the structure of the visit are continuously reviewed to achieve the best transmission of the message.

\subsection{Awareness raising workshops}

One of the initiatives proposed for this project is to work with groups of young people organized within the villages. The objective is to think about the reality of the village in terms of the conservation of its heritage through dynamics and games of reflection.

The content of the workshops is adapted to the ages, between 12 and 18 years old, and it is done in short thematic blocks as knowledge pills.

In addition, to evaluate the level of involvement of these groups, a small research practice on their community is developed in parallel to the workshops. The methodology applied for this part has oral memory as the main instrument. Following the speech of Paul Thompson, who already in 1978 proposes the following:

Oral history is a History built around people. It introduces life into History, and that broadens its scope. [...] It encourages students and teachers to work side by side. It introduces History into the community and draws from it. It helps the less privileged, and especially the elderly, in their search for dignity and self-confidence. It promotes contact -and consequently understanding- between social classes and between generations. [...] In other words, it acts in the interests of more complete human beings. (Thompson, 1978, p.29) 
With oral memory as a vehicle, it is possible to reconstruct the image of a community towards its village. Therefore, this is a work that not only helps young people to reflect on their heritage but also aims to leave an imprint on the community that helps to shed light on the scarce historical record they have.

On the other hand, guided research makes it possible to create a space of relationship between generations in which they share stories, myths, legends, and beliefs. This meeting favours the listening of the older generation but also gives the young people the possibility to share the vision they have of their environment today.

All the work, both workshops, and research is carried out in conjunction with a team of two facilitators trained in heritage and social knowledge with young people. This is one of the spaces where more work is done between disciplines outside the restoration work. Indeed, the analysis of this practice is useful to review the dissemination discourses in the other areas of the project (training and restoration work).

In short, it is once again a multidisciplinary work that aims to bring the community closer to its heritage through reflection and, in this way, achieve greater involvement in the process of its restoration.

\subsection{Documentary research}

The third line of work within the Open for Restoration programme covers documentary research into the historical data on the village and the heritage element being worked on.

The starting points are obtained in two ways: the testimonies shared by those attending the guided tours and the document management of the institutions involved in the project.

In this case, a search is made together with the owner for documentation concerning the management of Catholic churches contained in the government books of the diocese to which they belong. To find this data, the research is focused on the study of the parish seats to which the churches belong, which have been changing over time.

Moreover, the life testimonies shared by the groups visiting the temple during its restoration are recorded in the reports generated after each one. With this qualitative information, it is gradually possible to reconstruct the image of the heritage building over the last few decades. The testimonies reveal the changing use within religious celebrations and its direct relationship with the institutions of the village and its inhabitants.

\section{RESULTS}

The participation methodology designed based on the project's objectives and created attending to the limiting factors of the context has favoured in each case a greater involvement of the communities in the restoration of their heritage.

Concerning the guided tours of the Open for Restoration program, the project has managed to increase the interest of the population of each village to people from outside the community who visit their heritage.

In both cases, the visits with the local community have dispelled doubts and internal criticism regarding the architectural solutions applied in the restoration. In other words, a space for dialogue and empowerment has been generated between the local population and the technical work team, which has been reflected in an appropriation speech before the visitors.

In the same way, this program has generated a bond of trustowner that has favoured the contribution of support in the different areas of restoration: donation of local materials, support by local volunteers in specific activities of the work, the cession of auxiliary spaces for the work, organization of permanent vigilance by the local population, participation of representatives of the local community in the guided visits, etc.

All this has been reflected in the interest and direct communication between the owner and the technical work team to answer questions about construction solutions on-site, make decisions regarding the heritage element jointly, and inform the community of progress and difficulties in the development of the project through local leaders.

On the other hand, through the systematization of the visits and the reports generated with the attendance data, it has been possible to evaluate the sense of belonging of the local population and visitors to heritage buildings with great historical and artistic value in the country.

The nationwide dissemination of the programme has resulted in a significant increase in temple visits. However, most of them have been supported by the implementing institution in moving to the field to overcome difficulties related to the state of conservation of the road.

All groups that have visited the churches so far belong both to the municipalities and their villages and to university level educational centres with careers related to cultural heritage management and tourism.

About the guideline of activities with young people, the implementation of the workshops has not been achieved to date. However, the basic methodological itinerary for the development of the project has been elaborated.

The historical research surrounding the temples is maintained as a challenge. Many difficulties have been encountered in finding and accessing management documentation. Few publications speak of the architectural structure of the element itself. Also, the search for internal management documentation is complicated since due to the transfer of parish headquarters much documentation has been lost over the years.

\section{CONCLUSIONS}

This work presents a methodology in cultural heritage restoration management with an integral perspective that achieves a scope with greater involvement of the local population in the restoration works that historically have seen the projects from a passive position.

It is a model that can be extrapolated to other small-scale villages that may have very diverse cultural contexts. From the study of the limiting factors, the guidelines with which the methodology to be used is designed are identified.

Usually, restoration projects have separated the lines of work of physical work and the social part. In this case, the inversion of this perspective is achieved by making the social part the driving force of the project and creating meeting spaces that bring the communities closer to the project. 
From this perspective, it has been possible to generate trust through transparency, to involve all the actors involved in a way that is proportional to their possibilities, to favour meeting and learning spaces through issues related to cultural heritage, to focus the discourse from the human perspective of those who live there without imposing or underestimating the capacity for analysis of the rural community itself, and to open up the relationship of the village to external visits once again.

In short, the application of qualitative methodologies helps to obtain communication keys for good development of the project and helps to empower the actors involved to achieve better use of the economic resources available in the restoration works.

\section{REFERENCES}

Chamber L., 2019. La Catedral. Ingenium ut aedificare. Fundación Juanelo Turriano. Madrid.

Conceição, P., 2019. Programa de las Naciones Unidas para el Desarrollo (PNUD). New York, EU.: PNUD. Recovered from: http://hdr.undp.org/sites/default/files/hdr_2019_overview__spanish.pdf

Mapa Temático Pobreza por Ingreso, 2019. Centro Nacional de Información del Sector Social. Tegucigalpa, Honduras: CNISS. Recovered from:

http://demo.ceniss.gob.hn/mapas/PobrezaPorIngreso.aspx

AECID, 2014. Marco de Asociación País, 2014-2018. Agencia Española de Cooperación Internacional para el Desarrollo. Madrid, España: AECID. Recovered from: https://www.cooperacionespanola.es/es/publicaciones?title=\&fi eld_autor_value $=\&$ field_anio_value $\% 255$ bvalue $\% 255 \mathrm{~d} \% 255 \mathrm{by}$ ear\%255d=\&field_pais_evaluacion_tid_i18n=164\&field_actor_ que_publica_tid_i18n=All\&field_tipo_publicacion_tid_i $18 \mathrm{n}=\overline{\mathrm{Al}}$ 1\&field_tipo_de_publicacion_nueva_tid_i18n=47\&field_mas_i nformacion_title $=\&=$ Buscar

Martos, M., 2016. Herramientas para la gestión turística del patrimonio cultural. Manual para gestores culturales. Ediciones Trea, S.L. Gijón (Asturias).

Thompson, P., 1988. La voz del pasado. Historia oral. Ediciones Alfons El Magnànim (Edición traducida, 1988). Valencia.

Viñals, M.J. et al., 2016. Plan Estratégico de Desarrollo Turístico Sostenible del Destino Colosuca. Mancomunidad Colosuca. Gracias (Honduras).

INE, 2018. Mapa Indicadores de Población por Municipio, 2013. Instituto Nacional de Estadística de Honduras. Tegucigalpa, Honduras: INE. Recovered from: https://www.ine.gob.hn/V3/

PAO, 2016. Programa Abierto por Obras Comunidad de Madrid. Madrid, España: Portal Comunidad de Madrid. Recovered from:

https://www.comunidad.madrid/publicacion/1354627414443

IPCE, 2018. Programa Abierto por Restauración, 2018. Instituto del Patrimonio Cultural de España. Madrid, España: Portal IPCE. Recovered from:

https://ipce.culturaydeporte.gob.es/noticias/2018/2018-10-30clausura-abierto-por-restauracion.html
PPA, 2010. Programa Patrimonitos, Patrimonio Mundial en Ávila. Ávila, España: Muralla de Ávila. Recovered from: http://muralladeavila.com/es/?option=com_k2\&view=item\&lay out=item\&id=140\&Itemid=263 